\title{
Syphilis in a Jamaican psychiatric hospital A review of 52 cases including 17 of neurosyphilis
}

\author{
AGGREY W. BURKE \\ Bellevue Hospital, Famaica
}

An early report of syphilis from the Caribbean area suggested the rarity of this disease as a cause of mental illness (Ireland, 1892). More recently a decreasing incidence of neurosyphilis was noted among racially similar persons in Uganda by Billington (1966), who attributed to penicillin the remarkable fall over the 20-year period reviewed. The low incidence in developed countries probably has a similar cause (Dewhurst, 1969; Dawson-Butterworth and Heathcote, 1970).

That the diagnosis of neurosyphilis has become difficult was stressed by Heathfield (1968). Joffe, Black, and Floyd, (1968), in reviewing seven cases, pointed out that the modified picture noted might have been due to courses of penicillin given previously to all their patients for other reasons. Hume (1964) suggested that subcurative therapy masks syphilitic disease, but he believed this to be eventually helpful to the community.

In Jamaica the predominantly Negro and rural population of almost two million has been exposed to two treponemal diseases. Thus, up to 1956, areas of high and low incidence of yaws were identified by Grant (1956), but by 1963 the yaws prevalence rate for the island was estimated to have been reduced to 16 per 10,000 population (Gentle, 1965) although certain rural areas still showed higher rates. A later study pointed out the difficulties presented to venereologists by the occurrence of the two diseases (Ashcroft, Miall, Standard, and Urquhart, 1967). In addition, the possibility of marked cross-immunity among the treponemal organisms was raised by Cannefax, Norins, and Gillespie (1967).

With the widespread use of penicillin since its introduction in this area, it seems likely that modified neurological syndromes might be present. However, unusual pictures have been identified since the 19th century, as pointed out by Cruickshank (1956) and Montgomery, Cruickshank, Robertson, and McMenemey (1964). These workers described the features Received for publication January 19, 1972

Address for reprints: 12 Cambrian Road, Richmond, Surrey of two neuropathic syndromes of uncertain aetiology seen at the University Hospital in Jamaica. Montgomery (1960) suggested a treponemal variant as of probable aetiological importance and Rodgers (1965) gave good supporting evidence of a syphilitic aetiology. Syphilitic involvement in spinal arachnoiditis has also been reported in Jamaica (Rodgers and Cruickshank, 1962). From other parts of the West Indies there have been other reports of unusual neurological presentations of syphilis (Habib, 1962).

Rodgers (1964) followed up her earlier studies, and having surveyed mental hospital patients, reported that 121 ( 15.6 per cent.) of 773 demented chronic long-stay patients had syphilis. However, of 71 undergoing lumbar puncture, only 41 had positive cerebrospinal fluid (CSF) findings. The present study was undertaken in an attempt to determine some of the features of syphilis in patients newly admitted to the psychiatric hospital.

\section{Methods}

During the 7-month period, January to July, 1971, 200 patients were admitted by the author to one of four admission wards at the only psychiatric hospital in the island. This represented 13.6 per cent. of the 1,541 patients $(63.3$ per cent. males and 36.7 per cent. females) admitted to the hospital over that period. The venereal disease reference laboratory (VDRL) test and the Reiter protein complement-fixation test (RPCFT) were carried out routinely on 198 of these patients and repeated in 25 instances. When indicated the fluorescent treponemal antibody absorption (FTA-ABS) test also was performed. Syphilis was diagnosed in patients with an adequate history of venereal infection and positive serum test results.

The CSF was tested on admission as indicated by evidence of neurological involvement or atypical psychiatric features. Altogether 34 patients were tested. Neurosyphilis was diagnosed in sero-reactive patients who had either neurological involvement or positive CSF findings or both.

Four groups were defined:

(1) Congenital syphilis.

(2) Neurosyphilis 
(3) Latent syphilis.

(4) No syphilis

Penicillin was the main form of therapy. One patient who was allergic to penicillin was given tetracycline instead.

The characteristics of the patients with syphilis are described.

\section{Results}

Positive routine serological test results were obtained in 44 patients and the results were equivocal in ten others. The FTA-ABS test was performed in nineteen cases.

Finally, on historical, ciinical, and serological grounds, 52 (26 per cent.) of the 200 patients were diagnosed as having syphilis. The distribution of the diagnostic groups is shown in Table $I$. The one patient with congenital syphilis presented with a behaviour disorder, but without neurological features.

As can be seen from Table I, the seventeen (8.5 per cent.) cases of neurosyphilis did not differ from the other two major groups in sex distribution. However, there was a marked difference in age distribution, 88 per cent. of neurosyphilitics being over 45 years of age. There was also a tendency for the neurosyphilis group to include more cases admitted for the first time $(76.5$ per cent.: thirteen of seventeen cases) than the latent syphilis group (50 per cent: seventeen of 34 cases) and the nonsyphilis group (39.8 per cent.: 59 of 148 cases). The two latter groups were also similar in distribution of functional psychoses.

Latent syphilis: depression six cases (17.6 per cent.), schizophrenia 25 cases ( 73 per cent.);

Non-syphilis: depression 28 cases (18.9 per cent.); schizophrenia 97 cases ( $65 \cdot 6$ per cent.).

It therefore seemed possible to characterize two distinct populations: an older one with syphilis and central nervous system (CNS) disorder showing dementia as the main feature and often admitted to hospital for the first time; and a younger one without physical signs of CNS involvement and having the symptoms of the functional psychoses.

Some of the characteristics of the seventeen patients with neurosyphilis are shown in Table II. Only one patient did not have a CSF examination.

TABLE I Distribution of patients by diagnosis, sex, and age

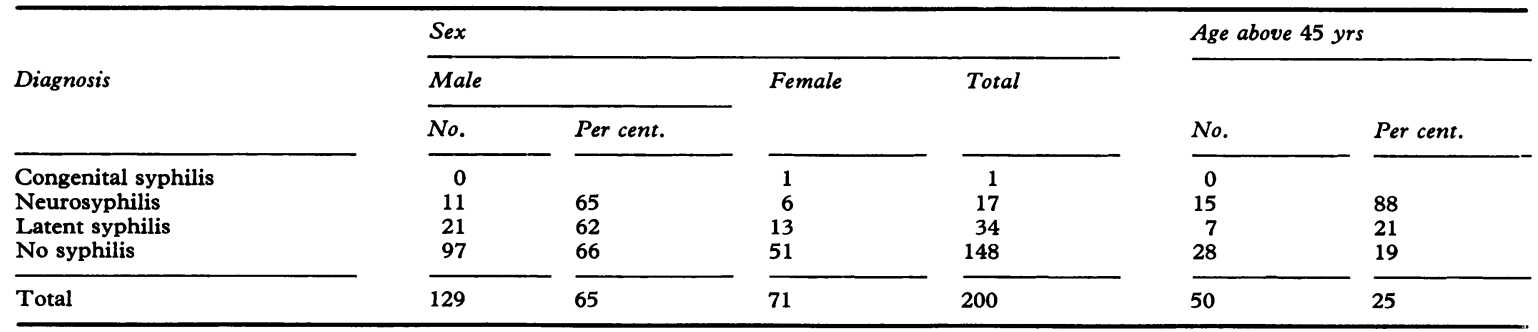

TABLE II Certain characteristics of seventeen patients with neurosyphilis

\begin{tabular}{|c|c|c|c|c|c|}
\hline Case no. & Age (yrs) & Sex & $\begin{array}{l}\text { Psychiatric } \\
\text { syndrome }\end{array}$ & $\begin{array}{l}\text { Serology VDRL, serum } \\
\text { (No. dilutions) }\end{array}$ & $\begin{array}{l}\text { No. of CSF findings } \\
\text { (Max. five) }\end{array}$ \\
\hline 1 & 70 & $\mathbf{F}$ & Dementia & 8 & 2 \\
\hline 2 & 62 & $\mathbf{M}$ & Dementia & WR & 1 \\
\hline 3 & 57 & $\mathbf{F}$ & Paranoia & 4 & $1^{a}$ \\
\hline 4 & 45 & $\mathbf{M}$ & Grandiose & 4 & $2^{a}$ \\
\hline 5 & 67 & $\mathbf{M}$ & Dementia & WR & 2 \\
\hline 6 & 60 & $\mathrm{~F}$ & Dementia & 8 & 0 \\
\hline .7 & 58 & $\mathbf{M}$ & Dementia & $\mathbf{W R}$ & 1 \\
\hline 8 & 60 & $\mathbf{M}$ & Dementia & 32 & 3 \\
\hline 9 & 55 & $\mathbf{M}$ & Dementia & 16 & $3^{a}$ \\
\hline 10 & 53 & $\mathbf{F}$ & Confusion & $0^{\mathrm{b}}$ & 0 \\
\hline 11 & 67 & $\mathbf{F}$ & Dementia & 2 & 2 \\
\hline 12 & 59 & $\mathbf{F}$ & Dementia & 128 & 1 \\
\hline 13 & 65 & $\mathbf{M}$ & Dementia & 8 & 1 \\
\hline 14 & 58 & $\mathbf{M}$ & Paranoia & 1 & 0 \\
\hline 15 & 54 & $\mathbf{M}$ & Depression & 2 & 0 \\
\hline 16 & 34 & $\mathbf{M}$ & Dementia & WR & 0 \\
\hline 17 & 30 & $\mathbf{M}$ & Dementia & 2 & 0 \\
\hline
\end{tabular}

a Includes reactive VDRL test

bFluorescent treponemal antibody absorption (FTA-ABS) test reactive

$\mathrm{WR}=$ weakly reactive (in less than one dilution) 
Of particular note were the high incidence of dementia as the main feature (12 patients); the higher incidence of cases with VDRL titre of over four dilutions, (6 of 17) compared with only two of 34 in the latent syphilis group; the low incidence of more than one positive finding in the CSF ( 6 patients); and the low incidence of reactive VDRL tests in the CSF (3 patients).

It was difficult to make exact diagnoses in all these patients. There were two cases (11 and 12) of meningovascular syphilis; five $(5,6,7,8$, and 9$)$ of general paralysis with significant neurological signs; and one further case (10) of congestive general paralysis. There were four cases considered to be of general paralysis but without significant neurological signs $(1-4)$. There were in addition five cases with isolated signs (13, right facial paralysis; 14, nerve deafness; 15, optic atrophy; 16, bladder disturbance; 17, involuntary movements).

Of the physical signs, reflex changes were the most frequent ( 5 cases 29.4 per cent.) and three of these $(5,6,7)$ also had extensor plantar responses. Four patients had wasting of calf muscles. Reflex iridoplegia was present in three cases ( 17.6 per cent.). There was no case of epilepsy.

Results of the CSF protein, globulin, colloidal gold, cell counts, and VDRL tests were analysed. Six patients had fluids normal in all respects; seven patients (41:2 per cent.) had a protein level of $40 \mathrm{mg}$. per cent. or more; six patients had an increase in globulins; the colloidal gold was positive in one case only (a paretic curve in Case 9); there was a pleocytosis in only two patients; and only three had positive results to the VDRL in the CSF.

The one patient who received tetracyline made a good response. The response to penicillin was good in ten patients, all of whom were discharged home. Disappointing results were obtained in six patients $(5,6,7,8,11,12)$ and these had to be transferred to other wards. Patient 12, who had meningovascular syphilis died some 3 months later.

\section{Discussion}

The major findings of this study were the high incidence of syphilis ( 26 per cent. of 200 unselected cases) and the fact that mental disturbance due to neurosyphilis accounted for 8.5 per cent. of these 200 cases. It was of interest that patients with latent syphilis resembled the psychiatric population on the ward, whereas they differed significantly in age and 'first admission' from patients with neurosyphilis. Our incidence of latent syphilis ( 17 per cent.) is similar to the island-wide laboratory figure of 20 per cent. 28,303 sero-reactive and weakly reactive) (Govern- ment Medical Laboratory, 1970). This slightly higher figure can be explained by the inclusion of mental hospital and venereal disease clinic attenders in the 140,579 patients and labourers tested. In this regard the study of Ashcroft and others (1967) deserves further mention. These workers found a marked difference in the total number of those who were sero-positive between a rural and a suburban community. Furthermore, they found that in a significant percentage of their patients a history of yaws was obtained. The findings in that study emphasized the difficulties in the diagnosis of syphilis in Jamaica. It was therefore likely that the incidences in the Government laboratory series, and in the present study might include many cases of persistent sero-reactivity due to former yaws infections. In this study, however, a diagnosis of syphilis was made on a history of infection as well as on serological evidence. The presence of former yaws could not have been ruled out completely; it would certainly have led to previous courses of penicillin. It is suggested that the high incidence ( 17 per cent.) of latent syphilis might be the result of high rates of internal immigration within the island. The frequent use of penicillin in the population is also believed to be an important factor in latent syphilis and in the modification of neurosyphilis.

The second important finding was the 8.5 per cent. incidence of neurosyphilis. In the chronic wards of the same hospital, Rodgers (1964) had noted a 15.6 per cent. incidence, using positive serological tests and dementia as her criteria. Though she did not exclude other causes in her patients, and no other criteria were used for diagnosis, the incidence she reported is not unexpected in view of the findings presented here. However, her other findings (Rodgers, 1965) and those of Habib (1962), both suggested the need to take neurological evidence and CSF changes into consideration. Moreover it is probable that the claims for a dramatic fall in the incidence of neurosyphilis advanced by Billington (1966) were also probably based on inadequate criteria. Had his requirement of a positive reagin test result in the CSF been insisted upon in this study, only three patients ( 1.5 per cent.) would have been considered to have had neurosyphilis.

Mention of two patients from this series will help to emphasize present day difficulties of diagnosis.

\section{Case reports}

Case 10, a 53-year-old woman, was readmitted to the hospital with a history of acute psychotic episodes, one 8 years ago and one 4 months ago. At these times she became very disturbed and smashed up her own property. 


\section{Examination}

She was confused, and showed a left facial paresis, and wasting of the calf muscles. 4 days after admission the paresis and confusion disappeared.

\section{Diagnosis}

She was suspected of having had a congestive attack of GPI, after extensive investigation and in spite of normal findings in the CSF.

Case 12, a 58-year-old woman, was admitted to hospital with a recent history of not being able to recognize her children and of showing features of Korsakow's psychosis. Later she became confused, aphasic, and apraxic, and over a short period gross dementing features appeared.

In spite of energetic treatment for meningovascular syphilis, her condition deteriorated and necessitated transfer to another ward where she died.

\section{Autopsy}

The presence of neurosyphilis was confirmed in spite of the negative VDRL test of the CSF.

The findings in these two cases were not unusual if we accept modification by previous penicillin therapy. In follow-up studies of mental hospital patients, the development of new central nervous system signs and symptoms unrelated to the reactivity of serological tests or cerebrospinal fluid characteristics has been noted; Dawson-Butterworth and Heathcote $(1970)$ and Wilner and Brody (1968) found in their respective studies that over 15-year and 10-year periods 65 and 39 per cent. of treated neurosyphilitics developed new signs.

Another significant observation in this connection was the finding by Cohen, Stout, and Ende (1969) of a much higher incidence of reactivity using the FTA-ABS test than was the case with the VDRL test. Furthermore, the persistence of organisms after treatment (Collart, Borel, and Durel, 1964) indicates preference for the former test, but in our situation, with a high incidence of syphilis and the expense of the FTA-ABS procedure, the use of this test is best limited to equivocal sero-reactors, patients with neurological signs, and patients with unexplained dementia or atypical psychotic features.

Other positive CSF findings in this study were also few. Protein change was the most common finding (Habib, 1962). This feature should be investigated more completely in future studies.

Tabes dorsalis has been stated to be rare in selected series of cases in tropical areas (Billington, 1966; Habib, 1962; Montgomery, 1960). This study did not produce any case of tabes and meningovascular syphilis was rare (two cases). The accepted prominence of simple dementia (Hahn and 12 others, 1959;
Dawson-Butterworth and Heathcote, 1970) was noted in this series. However, bizarre delusions of grandeur still merit a detailed search for syphilis, for of the 200 patients four of five such patients had general paralysis of the insane.

The most striking neurological finding was the absence of epilepsy. Pupillary changes were rare (17.6 per cent.), whereas reflex changes $(29.4$ per cent.) and muscle wasting (23.5 per cent.) were more common. Rodgers (1964) found incidences of 19 and 37.3 per cent. for pupillary changes and reflex changes respectively in her series. The results of these two studies differ markedly from the $58 \cdot 2$ per cent. incidence of pupillary changes and 51.6 per cent. of reflex changes found by Dewhurst (1969) in England. In this regard one may speculate as to possible additional modifying aetiological factors. Thus the findings of patients with amblyopia Degazon, 1956; Behrman, 1962) and neuropathies (Money, 1958; Montgomery, 1960) with nutritional deficiences has been noted. Another possibility is that age is a modifying factor, for in this study $\mathbf{8 8 . 2}$ per cent. of patients with neurosyphilis were over 45 years old.

Regarding the outcome of therapy in these seventeen patients with neurosyphilis, the poor response in six which necessitated transfer to a long-stay ward was disappointing. All these patients had severe symptoms and signs on admission. This high chronicity rate (35.3 per cent.) must surely be due to late diagnosis in these cases, and indicates the need for more widespread screening services. Hahn and others (1959) have pointed out that the prognosis of GPI is related to the severity of the initial psychosis.

The major conclusion that was reached from this review was that syphilis and its sequelae are still commonly found in Jamaica. Furthermore, the changed picture provides problems in diagnosis. It was difficult to substantiate the suggestion made by Hume (1964) that the community might eventually be helped by inadequate penicillin therapy, for the contrary seems to be the case.

\section{Summary}

Syphilis was diagnosed in 52 of 200 patients in an admission ward at the psychiatric hospital in Jamaica. Seventeen ( 8.5 per cent.) had neurosyphilis, tabes dorsalis was absent, meningovascular syphilis was rare (two cases), GPI was common (10 cases), and five cases were unclassified.

The present-day difficulties in diagnosis associated with previous inadequate penicillin therapy are stressed. A disappointingly high chronicity rate of 35.3 per cent. was noted among the neurosyphilis patients, one of whom died. 
I am grateful to Dr. Pamela E. B. Rodgers for encouragement and helpful advice, and to the staff of the Serological Laboratory at the University Hospital for carrying out additional tests. I should like to thank Dr. C. C. Gordon for making the 1970 Report of the Government Laboratory available to me.

\section{References}

Ashcroft, M. T., Miall, W. E., Standard, K. L., and Urquhart, A. E. (1967) Brit. F. vener. Dis., 43, 96

Behrman, S. (1962) Brit. F. Ophthal., 46, 554

Billington, W. R. (1966) E. Afr. med. f., 43, 469

Cannefax, G. R., Norins, L. C. and Gillespie, E. J. (1967) Ann. Rev. Med., 18, 471

Cohen, P., Stout, G., and ENDE, N. (1969) Arch. intern. Med., 124, 364

Collart, P., Borel, L. J., and Durel, P. (1964) Brit. F. vener. Dis., 40, 81

CRuickshank, E. K. (1956) W.I. med. f., 5, 147

Dawson-butterworth, K., and Heathcote, P. R. M. (1970) Brit. F. vener. Dis., 46, 295

Degazon, D. W. (1956) W.I. med. F., 5, 223

Dewhurst, K. (1969) Brit. f. Psychiat., 115, 31

Gentle, C. H. K. (1965) Brit. F. vener. Dis., 41155

Government Medical Laboratory (1970) 'Annual Report'. Ministry of Health, Jamaica

Grant, L. S. (1956) W.I. med. f., 5, 97

HABIB, G. B. (1962) Ibid., 11, 100

Hahn, R. D., Webster, D., Weickhardt, G., Thomas, E., Timberlake, W., Solomon, H., Stokes, J. H., Moore, J. E., Heyman, A., Gammon, G., Gleeson, G. A., CurTis, H. C., and Cutler, J. C. (1959) $A M A$ Arch. Neurol., 81, 557
Heathfield, K. W. G., (1968) Brit. med. F., 1, 765

Hume, J. C. (1964) Med. clin. N. Amer., 48, 721

Ireland, T. (1892) Brit. Guiana med. Ann., 4, 102

JOFFe, R., BlaCK, M. M., and Floyd, M. (1968) Brit. med. F., 1, 211

MONEY, G. L. (1958) W. Afr. med. F., 7, 58

MONTGOMERY, R. D. (1960) W.I. med. f., 9, 244

- Cruickshank, E. K., Robertson, W. B., and MCMENEMEY, W. H. (1964) Brain, 87, 425

Rodgers, P. E. B. (1964) 'Report on Survey, Bellevue Hospital'. MRC Unit, Jamaica

- (1965) W.I. med. F., 14, 36

- and Cruickshank, E. K. (1962) Ibid., 11, 164

WILNER, E., and BRODY, J. A. (1968) Lancet, 2, 1370

La syphilis dans un hôpital psychiatrique de la Jamaïque. Revue de 52 cas dont 17 de neurosyphilis

SOMMAIRE

La syphilis fut reconnue chez 52 malades parmi 200 d'un service d'admission d'un hôpital psychiatrique de la Jamaïque. Dix-sept (8,5 pour cent) avaient une neurosyphilis; aucun cas de tabes ne fut observé, la syphilis méningo-vasculaire fut rare ( $2 \mathrm{cas})$, la P.G. commune (10 cas); 5 cas ne purent être classés.

On souligne les difficultés actuelles de diagnostic en relation avec une pénicillinothérapie antérieure inappropriée.

Un haut taux de chronicité, décevant, s'inscrivit à 35,3 pour cent parmi les malades atteints de neurosyphilis; l'un d'eux mourut. 